\title{
Problems and Challenges of Online Lectures in Indonesia During the Pandemic COVID-19
}

\author{
Sonezza Ladyanna ${ }^{1 *}$ Aslinda $^{2}$ \\ ${ }^{1}$ Indonesian Department, Universitas Andalas, Indonesia \\ ${ }^{2}$ Indonesian Department, Universitas Andalas, Indonesia \\ *Corresponding author.Email: sonezzaladyanna@hum.unand.ac.id, ladyannasonezza@gmail.com
}

\begin{abstract}
The impact of the Covid19 pandemic on education is forcing lectures to be carried out online. The purpose of this article is to explain the problems and challenges of online lectures in Indonesia at the beginning of the Covid19 pandemic. Sources of data in this study were Undergraduate students of Andalas University in the Pragmatic class. Data obtained through observation and interviews. The analysis was carried out in a qualitative manner. Based on the research, it was concluded that the problems faced by students in taking online lectures were problems with the internet, electricity, online devices, environment, personal problems, and unattractive learning. These problems are challenges for lecturers and the government. For lecturers, lecturers must improve their ability to use online learning applications. The challenge for the Indonesian government is to even out development that supports online lectures, such as electricity supply that reaches all corners of the country, internet networks that are available in all corners of the country at the same speed anywhere, the government needs to make a policy regarding subsidizing online learning tools such as smartphones, laptops, or computers for the middle to lower economic community. Thus, online lectures will be able to run smoothly while improving the student mindset regarding the right course.
\end{abstract}

\section{Keywords: online lectures1, pandemic covid19, student problems, lecturer challenges}

\section{INTRODUCTION}

In 2020, in connection with the Covid19 pandemic, it will be a year full of challenges for people across the country, challenges in various aspects of life. People's habits are forced to change in order to avoid the spread of this virus and have various effects on all aspects of people's lives in all countries in the world. Various activities conducted through the Internet network sought to avoid physical contact between people so that the rate of transmission of this virus can be derived.

In the world of education, learning activities are carried out in full through various virtual spaces, pages and applications. Even though online learning is not new, but for people in Indonesia who do not have the facilities equally, it certainly creates problems and challenges. Moreover, suddenly total online learning has to be implemented.

Since 2009, the concept of online learning has begun to be applied to teachers in Indonesia but they face challenges to change the traditional teaching mindset[1]. The situation and conditions did not support the implementation of online learning at that time. However, due to the Covid19 pandemic, like it or not, learning must be online.

Therefore, research was carried out on the problems and challenges in online lectures in developing countries during the Covid19 pandemic. This research is focused on the beginning of the online lecture policy, especially in universities in the Pragmatics subject.

\subsection{Related Work}

With regards to online learning, several studies state that the constraints of online learning that are on a large scale in Indonesia due to the impact of the Covid19 pandemic are uneven internet networks and students, teachers and parents who are not used to[2]. Other research states thatstudent level barrier had the highest impact on e-learning use. In addition, the student level barrier showed strong positive correlation with the school level barrier and curriculum level barrier[3]..

Meanwhile, research results in other countries state that for a sample of 186 students, taking nine courses at the Open University of Catalonia, are discussed in the light of feedback, which is considered a central element in university teaching practice in online environments that, in general, the presence of feedback is associated with improved levels of performance and higher levels of satisfaction with the general running of the course[4].

\subsection{Our Contribution}

The discussion in this article is indispensable for educational policy makers to solve the problems and 
challenges faced by students and lecturers in Indonesia and other countries who have the same problem in carrying out lectures online. In addition, it also contributes to the government in general in designing the development of public facilities (especially internet and electricity networks) in an equitable manner. This article also contributes to teachers of pragmatics courses in preparing online learning strategies.

\subsection{Paper Structure}

This article is organized into several sections. Part 1 is an introduction containing the background, research objectives, research that has been done, and the contribution of this article. Furthermore, section 2 contains the research method, namely how the data is obtained and how the analysis is carried out. Furthermore, section 3 is a description of the problems and challenges in online lectures in Indonesia during the Covid19 pandemic and the discussion is described in section 4.Then, conclusions and suggestions are in section 5 .

\section{METHOD}

This research is a qualitative research. Sources of data in this study are undergraduate students and lecturers in the Pragmatics lecture in the Indonesian Literature Department, Faculty of Cultural Sciences, Andalas University, Indonesia. This research was conducted at the beginning of the Covid19 pandemic, namely in the even semester of 2019/2020, February to May 2020, to be precise. The data from this study are the problems faced by students in taking online lectures and the challenges faced by lecturers in teaching online lectures. Data obtained through observations during lectures and interviews with students.

Then, the data obtained were analyzed in relation to education as well as the situation and conditions in Indonesia which still did not have evenly distributed facilities and infrastructure. Furthermore, the findings are described and the appropriate solution is determined to overcome them.

\section{PROBLEMS AND CHALLENGES IN ONLINE TEACHING IN INDONESIA}

Problems faced by students of Pragmatics classes in developing countries in taking courses online are problems with the internet, electricity, online devices, environment, personal problems, and unattractive learning.

\subsection{Internet}

The internet network is a vital requirement in online learning because the process of transferring knowledge, discussions and other activities uses the internet network. If the internet network has problems such as unstable, slow, expensive, and even non- existent, then the lecture will not run. This is a problem faced by students (as well as lecturers) in taking online lectures. Most of the students returned to their hometowns when the Covid19 pandemic started. Andalas University students come from various regions and even from outside the province. Not all students come from areas with stable internet networks.

Even though they have walked up to $10 \mathrm{~km}$ from his residence, there is no internet network yet. Meanwhile, the government has imposed social restrictions that prohibit people from using public transportation. Walking to find an area that has an internet network is also not a good solution for them because they have to pass through tropical forests which are not so safe because of fear of wild animals.

Even if the area is covered by the internet network, it will not be strong enough to be able to access teaching materials or do videocall. Students find it difficult to access teaching materials and take part in video conferences held by lecturers because of insufficient internet power.

In addition, the costs incurred to get internet quota are not cheap for all students. With the diversity of parents' economic incomes, the limitations of the student's economy, the internet has become an expensive commodity for some students in Indonesia.

\subsection{Electricity}

The next problem is the problem of the electricity network. The electricity supply in a small number of regions in Indonesia is still not optimal. There are still people who have not been able to access electricity. In addition, the electricity went out without prior notice. Meanwhile, the gadgets used certainly require an electrical network. Likewise, the internet network in several areas is still very dependent on electricity supply.

\subsection{Online Devices}

The tools most needed in online learning are online devices such as smartphones, laptops, or computers. For the smooth running of lectures, of course, we need a device that has technology that supports the required applications.

However, not all students have the ability to buy these tools. The people's economy in Indonesia fell by $5.32 \%$ in the second quarter of 2020 , one of the reasons is the Covid19 pandemic[5]. The effect of this pandemic has resulted in the workforce losing income, resulting in a decrease in people's purchasing power so that people are very careful in managing expenses[6]. Therefore, emergency devices such as smartphones, laptops, or computers are not the main priority of the community during the Covid19 pandemic. 


\subsection{Social environment}

The next problem in online lectures is the environment. The environment in question is the awareness of the people around the students in providing space and study time for students. Several students stated that an environment that did not give them time or space was a problem that disrupted online lectures.

The wrong concept among people in their community regarding the concept of online learning that thinks studying at home is not as important as studying on campus. Being at home means taking a vacation is a thought that results in them being unable to study in peace. Parents, other families, or people around them often invite them to play, tell them to help with their parents' or family's work, and other things become a problem in learning online from home.

\subsection{Personal problems}

Personal problems are latent problems that become enemies in the world of education. The personal problem in question is the desire to learn from the student concerned.

Based on the results of the study, several personal reasons were found in students that caused them to be lazy to concentrate on taking online lectures. First, they are not interested in the subject. This is correlated with compulsion by parents and circumstances in choosing the major of interest. Second, this is due to the idea that attending lectures is only to fill in the attendance list so that they are considered present and eligible to take the final exam. Finally, the goal of gaining knowledge is drowned out by the goal of satisfying others and fulfilling administrative procedures.

\subsection{Uninteresting Learning}

The next problem is uninteresting learning. Students stated that the lecture system with monotonous material resulted in them being bored in following lectures, especially if lecturing online. The lecture system with monotonous material is the delivery by the lecturer who only delivers material such as in textbooks, only theories, without adding examples and not interactively with students.

These problems are a challenge for lecturers in achieving lecture goals. These challenges are providing online lectures that can be accessed by all students, providing support for students to be able

The implementation of online lectures in Indonesia, especially the Pragmatics class, Andalas University raises several problems, namely problems with the internet, electricity, online devices, environment, personal problems, and unattractive learning. Meanwhile, at other universities, the obstacles for students in studying online were mostly difficulty understanding the material, namely as many as 33 to attend lectures carefully, and increasing the ability to transfer knowledge so that it is not monotonous.

Lecturers must prepare teaching materials in easyto- understand packaging. The application used must be able to accommodate all students with their problems, although not all must be accommodated by the lecturer. Like the problem of the internet network and electricity supply, it is not a student problem that should be a challenge for lecturers only. However, it is the government's responsibility to provide equitable educational development for students throughout Indonesia.

\section{DISSCUSSION}

In fact, online learning is not something new that was suddenly created during the Covid19 pandemic. Several studies have been conducted on online learning, long before the pandemic Covid 19. Allen and J. Seaman said that recent survey of higher education in the United States reported that more than 2.35 million students enrolled in online courses in fall 2004, this report also noted that online education is becoming an important long-term strategy for many postsecondary institutions[7]. Another 1999 study concluded that online courses are best when they arc engineered to take advantage of the learning opportunities afforded by the online technologies, rather than being used as supplements to conventional teaching programs[8].

At Andalas University, before the Covid19 pandemic occurred, the leadership through the Education Quality Development Institute (LPMP) had repeatedly conducted online training and tutoring for Andalas University lecturers. In fact, several teaching materials in general Indonesian courses have been made and published, but they are only limited to blended learning, such as historical materials, functions, positions, and roles of the Indonesian language which are made in the form of videos and shared through the youtube application via the https:// link. www.youtube.com/watch? $\mathrm{v}=\mathrm{J} 7$ AcwdqRZ4o\&t=560s.

However, full online application has not been carried out before the pandemic occurs so when a pandemic occurs which requires everyone to study from home and restrictions on physical contact are required, the lecture process must be carried out completely online. Thus, schools are experiencing a paradigm shift, schools that initially focused on traditional academic skills suddenly have to move to online learning which tends to provide opportunities for critical thinking skills and adaptability[9].

people $(66 \%)$, as many as 8 people $(16 \%)$ stated that there was a lack of internet quota, as many as 8 people $(16 \%)$ stated that they had difficulty getting internet access. , and 1 person (2\%) stated that he did not understand the online lecture application[10].

Other studies also mention that $50 \%$ of students do not have a laptops, and $80 \%$ of students are difficult to get 
signals and wasteful in using a data plan because many students live far from urban areas. The study was not effective because as many as $61.5 \%$ of students stated they never used online learning media before the covid19 pandemic[11].

These problems are challenges for lecturers and the government. For lecturers, lecturers must improve their ability to use online learning applications. Lecturers must be able to make interesting and acceptable teaching materials in the era of education 4.0. Basically, the Covid19 pandemic forced the unsuccessful 4.0 education program to run. Before pandemic, some of discourse, supporting policies, and socialization about the era of education 4.0 were not successful. But Covid-19 gave an extraordinary impact on digital transformation towards the educational era 4.0 .

Broadly, the success of online learning in Indonesia during the COVID-19 Pandemic was determined by the readiness of technology in line with the national humanist curriculum, support and collaboration from all stakeholders, including government, schools, teachers, parents and the community[12].

The findings in this study are a sample of the problems of students in Indonesia in general. Therefore, the challenge for the Indonesian government is to level the development that supports online lectures, such as electricity supply that reaches all corners of the country, internet networks available in all corners of the country at the same speed anywhere. Not only the problem of equal distribution of internet network coverage and the quality of speed that is evenly distributed, but also economic problems in obtaining internet quotas also require government attention, such as free internet quotas for education - given the economic situation of Indonesian society. In addition, the government needs to make a policy regarding subsidizing online learning tools such as smartphones, laptops, or computers for the middle to lower economic community. Thus, online lectures will be able to run smoothly while improving the student mindset regarding the right course.

\section{CONCLUSION}

Based on the data and discussion, we can conclude several things. First, the problems faced by Indonesian students in taking online lectures are problems with the internet, electricity, online devices, the environment, personal problems, and unattractive learning. Second, the challenge for lecturers in conducting online lectures in connection with the problems faced by students is that lecturers must improve their ability to use online learning applications. Lecturers must be able to make interesting and acceptable teaching materials in the era of education 4.0. In addition, the government must also build infrastructure so that electricity supply and internet networks are evenly available in all corners of the country. The government must also make policies related to subsidizing online learning tools, especially for middle and lower economic communities. Like it or not, online lectures must be carried out and all parties must increase enthusiasm and positivism in studying.

\section{ACKNOWLEDGMENT}

This work was supported by PPMP Project, LP3M Universitas Andalas

\section{REFERENCES}

[1] E. R. Sari, "Online learning community: a case study of teacher professional development in Indonesia," Intercult. Educ., vol. 23, no. 1, pp. 63-72, Feb. 2012, doi: 10.1080/14675986.2012.664755.

[2] Z. Zaharah, G. I. Kirilova, and A. Windarti, "Impact of Corona Virus Outbreak Towards Teaching and Learning Activities in Indonesia," SALAM J. Sos. dan Budaya Syar-i, vol. 7, no. 3, pp. 269-282, 2020.

[3] A. Almanthari, S. Maulina, and S. Bruce, "Secondary School Mathematics Teachers' Views on E-learning Implementation Barriers during the COVID-19 Pandemic: The Case of Indonesia," Eurasia J. Math. Sci. Technol. Educ., vol. 16, no. 7, p. em1860, 2020.

[4] A. Espasa and J. Meneses, "Analysing feedback processes in an online teaching and learning environment: an exploratory study," High. Educ., vol. 59, no. 3, pp. 277-292, 2010.

[5] B. P. Statistik, "No Title," 2020. https://www.bps.go.id/pressrelease/2020/08/05/ 1737/-ekonomi-indonesia-triwulan-ii-2020- turun-532-persen.html.

[6] A. K. Pakpahan, "Covid-19 Dan Implikasi Bagi Usaha Mikro, Kecil, Dan Menengah," J. Ilm. Hub. Int., pp. 59-64, 2020.

[7] K.-J. Kim and C. J. Bonk, "The future of online teaching and learning in higher education," Educ. Q., vol. 29, no. 4, pp. 22-30, 2006.

[8] R. Oliver, "Exploring strategies for online teaching and learning," Distance Educ., vol. 20, no. 2, pp. 240-254, 1999.

[9] B. Salkiah, "PERUBAHAN PARADIGMA PENDIDIKAN DAN EKONOMI DIMASA PANDEMI COVID-19," MEDIA BINA Ilm., vol. 15, no. 1, pp. 3781-3788, 2020.

[10] S. Riadi, E. N. Normelani, M. Efendi, I. Safitri, and G. F. I. Tsabita, "Persepsi Mahasiswa Prodi S1 Geografi FISIP ULM Terhadap Kuliah Online Di Masa Pandemi Covid-19," PADARINGAN (Jurnal Pendidik. Sosiol. Antropol., vol. 2, no. 2, pp. 219227, 2020.

[11]N. K. S. Astini, "Tantangan Dan Peluang Pemanfaatan Teknologi Informasi Dalam Pembelajaran Online Masa Covid-19," Cetta J. Ilmu Pendidik., vol. 3, no. 2, pp. 241-255, 2020. 
[12] R. R. Aliyyah, R. Rachmadtullah, A. Samsudin, E. Syaodih, M. Nurtanto, and A. R. S. Tambunan, "The Perceptions of Primary School Teachers of Online Learning during the COVID-19 Pandemic Period: A Case Study in Indonesia," J. Ethn. Cult. Stud., vol. 7, no. 2, pp. 90-109, 2020. 